\title{
EDITORSKÁ POZNÁMKA
}

Za motto předkládaného čísla AUC - Philologica, Translatologica Pragensia lze považovat název stejnojmenného workshopu, pořádaného v r. 2018: Cesty translatologie. Setkávají se zde jak texty zkušených badatelů v oblasti zejména literárního překladu a jeho dějin a kritiky, tak autorů začínajících, s osobními svědectvími o cestách, jimiž překladatelství, bádání i výuka v této oblasti v posledních desetiletích prošly.

Do první skupiny př́spěvků patří nesporně práce Bohuslava Mánka, který se ve své studii Počátky české kritiky uměleckých překladů z angličtiny $v$ devatenáctém století: od recenzí $k$ teorii zaměřuje na počátky a rozvoj české kritiky překladu v devatenáctém století. Anita Hutková se ve svém príspěvku The Issue of Expression Hybridity in the Translation Process věnuje na základě prózy mad’arského autora P. Esterházyho, jejího slovenského překladu R. Deákové a prózy české autorky Dory Kaprálové vnímání hybridity jako reality v literárním a translačním prostoru. Studie Stanislava Rubáše České preklady Jesenina a sovětská ideologie podává obraz proměn vize tohoto ruského básníka v jednotlivých obdobích vývoje českého překladatelství i společnosti jako celku.

Druhou skupinu textů představují příspěvky studentek a studentů doktorského a magisterského studia jako ukázka potenciálního dalšího směřování translatologických bádání. Michal Brabec se zabývá vzájemnými vztahy dvou středně velkých kultur (české a katalánské) a ve své studii představuje odborné veřejnosti osobnost překladatele Jana Schejbala a jeho vliv na recepci katalánsky psané literatury u nás. Elizaveta Getta ve svém příspěvku LEVÝ, Jiří. Umění prekladu. Tři fáze překladatelovy práce. Translatologická analýza českého a německého vydání využila, vedle teoretických znalostí, rovněž práci s dosud nezpracovanými archívními materiály. Na otázky překladu méně studovaných literárních žánrů se zaměřila Tereza Marková ve své práci Modely pro analýzu překladu "hudby do slov" v cizojazyčné beletrii a jejích českých převodech. Otázka překladatelské praxe stojí v popředí příspěvku autorek Annamárie Péntek a Elizabeth Körosové Aktuální problematika, tendence a metody česko-mad’arského uměleckého prekladu. Zcela ojedinělé postavení mezi prríspěvky doktorandi̊ zaujímá pak díky svému metodologickému zaměření studie Kateřiny Středové Archivní prameny v translatologickém výzkumu - kde je hledat a jak $s$ nimi pracovat? Petr Kabelka ve svém příspěvku představuje projekt Kritika prekladu včera, dnes a zítra řešený na Univerzitě Palackého $v$ Olomouci.

$\mathrm{O}$ tom, že cesty translatologie i překladu mohou být někdy klikaté, svědčí rovněž poslední oddíl tohoto čísla, nazvaný výstižně jeho pořadatelkou Evou Kalivodovou Dvě výjimečné jubilantky v oboru: Jarmila Emmerová a Eva Masnerová. Nejde jen o standardní 
připomenutí životního jubilea dvou vynikajících osobností českého překladu a vysokoškolských pedagožek, ale na základě vzpomínek bývalých studentek a studentů rovněž o významné svědectví o stavu a vývoji nejen literárního překladu a jeho výuky v poslední třetině dvacátého století a v prvních desetiletích století jedenadvacátého.

Poděkování za vstřícnost při př́ípravě AUC Philologica, Translatologica Pragensia patř́i rovněž všem recenzentkám a recenzentům od nás i ze zahraničí, kteří nesporně přispěli ke kvalitě jednotlivých př́spěvků a pro přispívající studenty se stali i velmi důležitou a citlivou zpětnou vazbou pro jejich další badatelské i publikační aktivity.

Jana Králová, jana.kralova@ff.cuni.cz 